\title{
Impact of Childhood Exposure to Intimate Partner Violence and Other Adversities
}

\author{
Kathleen M. Franchek-Roa', Agnes Tiwari², Annie Lewis-O'Connor ${ }^{3}$, and Jacquelyn Campbell ${ }^{4}$ \\ ${ }^{1}$ Department of Pediatrics, University of Utah School of Medicine, Salt Lake City, UT, USA \\ ${ }^{2}$ Li Ka Shing Faculty of Medicine, The University of Hong Kong School of Nursing, Hong Kong, China \\ ${ }^{3}$ Department of Medicine, Brigham and Women's Hospital, Boston, MA, USA \\ ${ }^{4}$ Johns Hopkins University School of Nursing, Baltimore, MD, USA
}

\begin{abstract}
Childhood exposure to intimate partner violence (IPV) and other adversities has been shown to have adverse effects on health and well-being not only in childhood but also throughout the lifespan. This paper focuses on the prevalence of childhood adversities including exposure to IPV. The intersection of adverse childhood experiences and IPV victimization/perpetration in adulthood is also explored. The neurobiology of trauma is discussed and by understanding the impact of trauma on health, it is hoped that enhancement of resilience is possible. Based on the identification of protective factors at the individual, familial, and community level, examples of interventions that encourage safe, stable, and nurturing relationships between parents and children are described.
\end{abstract}

Key Words: Childhood; Adversities; Intimate partner violence; Intersection; Trauma; Health; Resilience.

Received: January 25, 2017 / Revision: February 27, 2017 / Accepted: February 27, 2017

Address for correspondence: Agnes Tiwari, Li Ka Shing Faculty of Medicine, The University of Hong Kong School of Nursing, William M.W. Mong Block, 21 Sassoon Road, Pokfulam, Hong Kong, China

Tel: +852-9202-6616, Fax: +852-3691-8566, E-mail: agnes_tiwari@hku.hk

\section{INTRODUCTION}

Intimate partner violence (IPV) is defined by the Centers for Disease Control and Prevention (CDC) as the use of "physical violence, sexual violence, stalking and psychological aggression (including coercive tactics) by a current or former intimate partner $\cdots ., 1)$ IPV is one of the most pervasive forms of victimization among women worldwide and significantly impacts the health and well-being of victims and their children. The World Health Organization (WHO) multi-country study found a lifetime prevalence of female IPV victimization to range from $15 \%$ (Japan) to $71 \%$ (Ethiopia). ${ }^{2)}$ Less is known about the prevalence of IPV victimization of males; however, a recent study in the US found that $36 \%$ of women and $29 \%$ of men had been a victim of IPV at some point in their lives. ${ }^{3}$ Women are at the greatest risk for IPV victimization during their child-bearing years; ${ }^{4}$ therefore, millions of children are exposed and impacted by exposure to IPV. ${ }^{5,6)} \mathrm{An}$ expanding scientific body of evidence is finding that violence victimization has a tremendous effect on the health and wellbeing of victims, perpetrators, and witnesses. This review will focus on 1) the prevalence of childhood violence and

This is an Open Access article distributed under the terms of the Creative Commons Attribution Non-Commercial License (http://creativecommons.org/licenses/by-nc/4.0) which permits unrestricted non-commercial use, distribution, and reproduction in any medium, provided the original work is properly cited. abuse exposure, specifically focusing on exposure to IPV; 2) the neurobiology of trauma; and 3) the burden that this 'disease of violence' has on the health of people and communities around the world. This is not meant to be an extensive review, but rather, a narrative of the health effects of violence on the family and how this knowledge can be used to help current and future generations.

\section{CHILDHOOD EXPOSURES TO INTIMATE PARTNER VIOLENCE AND OTHER ADVERSITIES ON LIFELONG HEALTH}

Since the adverse childhood experiences (ACE) study ${ }^{7)}$ was published in 1998, there has been an evolving realization in the medical community that adversity and trauma experiences for children are 1) extremely prevalent; 2) associated with many of the leading contributors to preventable death; ${ }^{8}$ and 3) a staggering burden on the health and wellbeing of the family. The ACE study ${ }^{7)}$ essentially laid the foundation for linking childhood maltreatment, household dysfunction (defined as having a caregiver who is mentally ill/ suicidal; absent due to incarceration/death/divorce; violent toward the mother; or abusing drugs or alcohol), growing up in poverty ${ }^{9,10)}$ and peer/community violence exposure, ${ }^{9,11)}$ to poor health not only in childhood but also throughout the 


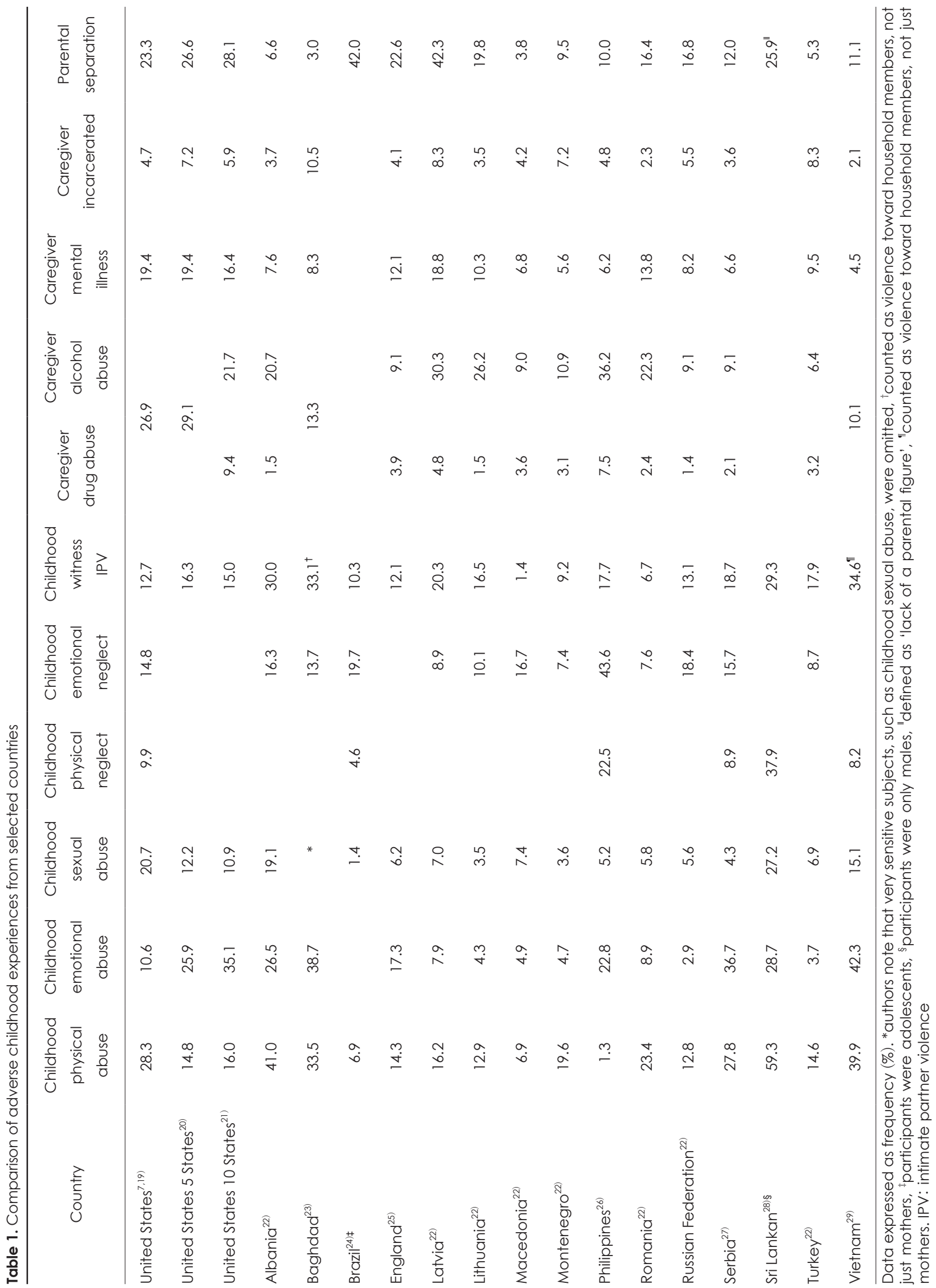


lifespan. An important finding of the ACE study and subsequent studies ${ }^{7,12-15)}$ is that children who have been exposed to one trauma are more likely to be exposed to multiple traumas and this phenomenon has been termed polyvictimization. ${ }^{16)}$ Polyvictimization is important to consider because poly-victims often have worse health and symptomatology than victims exposed to only one form of trauma. ${ }^{17)}$ Other researchers have conceptualized this exposure as cumulative trauma pointing out that not only is there trauma from exposure to violence throughout childhood and adolescence but especially for those in marginalized racial/ethnic, religious, and gender identity/sexual preference groups where there is also exposure to structural racism, micro-aggressions and historical trauma. ${ }^{18)}$ The more cumulative trauma, the more profound the effects on health.

Table 1 shows the prevalence of ACEs and Table 2 shows the ACE score in selected studies from the US and from countries around the world. ${ }^{719-29)}$ Although the studies had some differences in methodologies and ACE questions, there are some notable comparisons. The highest incidences of ACEs are found in the following countries: Sri Lankan men ${ }^{28)}$ had the highest incidences of childhood physical abuse (59.3\%), childhood sexual abuse (27.2\%), childhood physical neglect (37.9\%); nearly tied with Albania ${ }^{25)}$ for witnessing domestic violence against the female caregiver (30\% Albania, 29.3\% Sri Lanka men); and had the highest prevalence of an ACE score of $>4$ ACEs (31.4\%). The Philippines had the highest incidence of a caregiver abusing substances (drug abuse 7.5\%; alcohol abuse 36.2\%). ${ }^{26)}$ The US had the highest incidence of children exposed to caregivers with mental illness $(19.4 \%){ }^{7,19,20)}$ Latvia $(42.3 \%)^{22)}$ and Brazil $(42 \%)^{24)}$ had the highest incidence of children exposed to parental separation. These comparisons illustrate the common theme of the ubiquity of trauma exposure for children worldwide.

The ACE study and a plethora of subsequent studies, both in the US and worldwide, have linked adversity in childhood to organic diseases later in life. When comparing the health of adults with no childhood adversity to those with multiple exposures, evidence finds that those with adversity are more likely to suffer from mental disorders; ${ }^{3,721,30-36)}$ sexually transmitted infections; ${ }^{37,38)}$ unintended pregnancies; ${ }^{399}$ chronic pain syndromes including headaches and migraines; ${ }^{3,34,40,41)}$ gastrointestinal problems; ${ }^{3,34,40)}$ chronic fatigue ${ }^{40)}$ sleep problems, ${ }^{3,40)}$ liver disease; ${ }^{7,30,31,42)}$ cancer; ${ }^{7,31,43-45)}$ obesity and adultonset diabetes; $;, 7,21,31,34,45)$ asthma and other chronic respiratory conditions; $;^{3,7,21,30,31,39,46,47)}$ cardiovascular disease ; $^{7,21,30,31,48,49)}$ stroke; ${ }^{7,21,31)}$ and premature death. ${ }^{42,50,51)}$ Such compelling findings beg for our attention in clinical practice and policy.

Similar to the adult literature, research on the health and well-being of children also finds this association between adversity and poor health. Children exposed to adversity as compared to children without these exposures are at an increased risk for social disruptions, such as perpetrating violence and being involved in the criminal justice system; ${ }^{52-56)}$ mental health and behavioral problems, such as depression, anxiety and attention-deficit hyperactivity disorder; ${ }^{57-66)}$ obesity; ${ }^{67-70)}$ asthma; ${ }^{71-73)}$ risk for cardiovascular disease; ${ }^{70,74)}$ multiple somatic complaints such as headaches, fatigue, gastrointestinal

Table 2. Comparison of number of ACEs from selected countries

\begin{tabular}{|c|c|c|c|c|c|}
\hline Country & 0 & 1 & 2 & 3 & $\geq 4$ \\
\hline United States ${ }^{7.19)}$ & 36.1 & 26.0 & 15.9 & 9.5 & 12.5 \\
\hline United States 5 States $^{20)}$ & 40.6 & 22.4 & 13.1 & 8.8 & 15.2 \\
\hline United States 10 States $^{21)}$ & 40.6 & & 44.1 & & 15.3 \\
\hline Albania $^{22)}$ & 30.3 & 22.7 & 16.9 & 16.3 & 13.8 \\
\hline Baghdad $^{23)}$ & $*$ & $*$ & $*$ & $*$ & $*$ \\
\hline Brazil $^{24)}$ & 15.0 & 39.0 & 28.0 & 12.0 & 5.0 \\
\hline England ${ }^{25)}$ & 53.6 & 22.7 & \multicolumn{2}{|c|}{15.4} & 8.3 \\
\hline Latvia $^{22)}$ & 28.0 & 28.7 & 18.6 & 10.6 & 14.1 \\
\hline Lithuania $^{22)}$ & 47.3 & 24.6 & 14.3 & 6.4 & 7.3 \\
\hline Macedonia ${ }^{22)}$ & 60.1 & 24.9 & 9.1 & 3.6 & 2.3 \\
\hline Montenegro ${ }^{22)}$ & 56.7 & 24.0 & 10.9 & 3.9 & 4.5 \\
\hline Philippines ${ }^{26)}$ & 26.8 & 24.7 & 18.8 & 13.8 & 9.2 \\
\hline Romania $^{22)}$ & 46.4 & 26.2 & 13.2 & 6.5 & 7.7 \\
\hline Russian Federation ${ }^{22)}$ & 49.9 & 27.8 & 11.6 & 5.4 & 5.4 \\
\hline Serbia $^{27)}$ & 49.2 & 22.9 & 11.6 & 7.8 & 8.5 \\
\hline Sri Lankan ${ }^{28) \dagger}$ & $\neq$ & $\neq$ & $\ddagger$ & $\ddagger$ & 31.4 \\
\hline Turkey $^{22)}$ & 56.7 & 22.1 & 10.9 & 5.3 & 5.0 \\
\hline$V$ ietnam ${ }^{29) \S}$ & 23.8 & 22.5 & 17.8 & 15.1 & 20.9 \\
\hline
\end{tabular}

Data expressed as frequency (\%). * not reported, 'participants were only males, ${ }^{\ddagger}$ not reported, ${ }^{\S} \mathrm{ACE}$ scores included peer/community violence. ACE: adverse childhood experiences 
problems; ${ }^{75)}$ poorer overall health; ${ }^{57,75,76)}$ and perhaps, the most disturbing, is the negative impact on the developmental and intellectual functioning of children. ${ }^{57,63,67,77-81)}$ The loss of the potential functional and intellectual capacity of people due to childhood violence exposure is daunting.

The link between adversity in childhood to morbidity and early death in adulthood was based on the observation that adults who had multiple ACEs, as compared to those with no ACEs, were more likely to adopt high risk health behaviors. ${ }^{7)}$ Felitti et al. ${ }^{7)}$ found that those adults who had four or more ACEs as compared to those adults who had none had adjusted odds ratio of 7.4 for being an alcoholic, 2.2 for being a current smoker, 4.7 for using illicit drugs, 10.3 for injecting drugs, 3.2 for being sexually promiscuous, and 12.2 for ever attempting suicide. Subsequent studies have found similar associations between number of childhood adversities and high risk health behaviors and this association remains robust over generations. ${ }^{31,32,41,50,82-86)}$ These high risk behaviors seem to be the mechanism or 'solution" that adults use to cope with the physical and mental anguish of their earlier childhood adversities. ${ }^{1031,87-89)}$ While no study has to date explored the relationship of adversity of childhood and sexual exploitation (i.e., human trafficking) anecdotal evidence suggests a strong correlation. This knowledge is invaluable and essential when treating patients with drug addictions, mental health challenges, health risk behaviors, and chronic illness.

In addition to the above mentioned ACEs, the past several decades research has also revealed dramatic differences in health outcomes based on such social determinants of health $(\mathrm{SDOH})$ as income, education, wealth, race and ethnicity. A Robert Wood Johnson Foundation report highlights the potential future use of SDOH data to inform and promote health and well-being. ${ }^{90)}$

\section{THE BIOLOGICAL RESPONSE TO ADVERSITY}

As the knowledge of adversity and the impact on the health and well-being of humans is expanding, another growing body of scientific evidence is helping to elucidate the potential biological mechanisms that may be involved in the ways that trauma impacts health. Utilizing the increasing knowledge on the health effects of chronic stress in childhood, the American Academy of Pediatrics has proposed a 'new' basic science of pediatrics, the 'ecobiodevelopmental framework. '91) This framework emphasizes how biology and ecology work synergistically to influence and shape the mental and physical components of a developing child. ACE, traumatic exposures and the environment are referred to as toxic stressors ${ }^{91}$ if these exposures disrupt the normal developmental trajectory of a child leading down a path of lifelong stress-related illnesses. About two decades ago, there was a paradigm shift from viewing biological systems as static systems (the concept of homeostasis) to dynamic, changing systems (the concept of allostasis $)^{92)}$ in response to external factors. Toxic stressors and the 'dose response' are thought to impact the 'allostatic load,' i.e., the cost of chronic exposure of stress to the individual ${ }^{92)}$ which is manifested as poor health and disease later in life. Allostatic load is "the wear and tear on the body" which is compounded over time when the individual is exposed to repeated or chronic stress. It represents the physiological consequences of chronic exposure to fluctuating or heightened neural and neuroendocrine responses that result from repeated or chronic stress.

One of the fundamental premises of the neurobiology of trauma is that children who are exposed to chronic maltreatment (abuse, violence or neglect) have elevated levels of stress hormones. ${ }^{88,89,93,94)}$ Research on brain physiology and neuroimaging studies ${ }^{89,93,95,96)}$ have found that certain regions of the brain are sensitive to chronically elevated stress hormones, specifically those areas of the brain densely populated with glucocorticoid receptors, such as the hippocampus, amygdala and cerebral cortex; and the timing of exposure is critical ${ }^{89,95,97)}$ These areas of the brain, along with other key structures (e.g., thalamus, hypothalamus, ventromedial prefrontal cortex) are involved in processing emotions, behavior, and motivation; storing memories; and the neuro-pathways for decision-making and impulse control. ${ }^{89)}$ It is no wonder that these areas of the brain have been shown to have alterations in patients with histories of abuse and mental illness. ${ }^{89)}$ The concept of sensitive periods to stress during child development is key to understanding that, for some brain structures, the first three to five years of a child's life appear to be the most critical in setting the future health trajectory ${ }^{89,95,97)}$ It has been proposed that the brain's response to stress is probably an evolutionary adaptation to enhance survival; ${ }^{98)}$ however, these physiologic and neurologic adaptions can lead to poorer health over the long term. ${ }^{93)}$

Changes in brain architecture, epigenetic mechanisms and advanced cellular aging due to toxic stress exposures are some of the proposed mechanisms by which adversity impacts the allostatic load of an individual affecting their lifelong health. Recent research into epigenetics and cellular aging provides a window into understanding other ways that trauma can influence health. Studies involving the epigenome provide plausible explanations of how the environment interacts with the genome, e.g., through regulating gene expression by changing DNA methylation patterns. ${ }^{99)}$ Another area of research is in telomere length. Telomeres are repetitive sequences of DNA at the end of chromosomes that are im- 
portant in the replication and stability of the DNA molecule. The length of telomeres shortens as humans age and premature shortening is associated with poor health and disease. Research has found accelerated telomere shortening in stressexposed children. ${ }^{100)}$ Ongoing research is needed to provide a more complete picture, but these areas of research provide intriguing links to trauma and disease.

\section{INTERSECTION OF ADVERSE CHILDHOOD EXPERIENCES AND INTIMATE PARTNER VIOLENCE}

With an understanding of how adversity in childhood may have lifelong effects on health and well-being, we now turn our attention to the intersection between ACEs and IPV. Focusing on the ACE of exposure to IPV highlights the association and synergistic effect that IPV exposure has on other childhood adversities. For example, studies have found that childhood exposure to IPV is a significant adversity in and of itself and is a major contributor to poor health outcomes independent of other adverse experiences. ${ }^{101)}$ In addition, IPV exposure increases the odds of experiencing other ACEs and increases the risk of adopting high-risk health behaviors in adolescence and well into adulthood. ${ }^{102)}$ More importantly, IPV exposure with other ACEs (i.e., sexual abuse) increases the risk of developing complex psychopathology in adulthood. ${ }^{36)}$ Evidence strongly supports that, growing up in a violent home affects children in a variety of ways, including experiencing child abuse and other ACEs and becoming perpetrators or victims of IPV in adulthood.

Childhood exposure to IPV is widespread. ${ }^{5,6,103)}$ Apart from the risk of injury and trauma as a result of being exposed to IPV, a range of adverse health consequences have been reported including cognitive, psychological, and emotional impairments. ${ }^{104,105)}$ Longer-term developmental problems, such as low self-esteem, depression, anxiety, physical aggression, and school failure are also more common among children growing up in violent homes. ${ }^{106-108)}$ Studies of children's exposure to IPV are to an extent limited by the considerable variation in definitions and reliance on retrospective reports from adult respondents. Previously, some common criteria of what constitutes children's exposure to IPV have been suggested including a child's visual or auditory witnessing of the violence, or his/her awareness of the consequences (e.g., injury of the victim, household damage, and police involvement). ${ }^{109)}$ In addition to cross-sectional and retrospective designs, longitudinal studies are needed so that the temporal sequencing of childhood violence exposure leading to adverse outcomes later in life can be studied and timely interventions implemented. Secondary analysis on large cohort studies such as the Nurs- es' Health Study ${ }^{110)}$ may also shed light on aspects of children's exposure to IPV that were not evident in smaller scale studies.

For children growing up in violent homes, in addition to exposure to IPV, there is also an increased risk of child abuse. In one study, the prevalence of physical child abuse was 57.5\% for adults who reported exposure to IPV as a child, which was significantly higher than the $21.7 \%$ reported by those with no prior childhood exposure to IPV. ${ }^{111)}$ This finding is consistent with the abundant evidence that child abuse and childhood exposure to IPV often co-occur. ${ }^{108,112-116)}$ In a much cited review of studies on the overlap between IPV and child abuse, ${ }^{112)} \mathrm{a}$ median rate of co-occurrence of $41 \%$ was reported with moderate to strong associations between child abuse and IPV. In another study involving a birth cohort from New Zealand, children in homes where their parents physically fought were at a three to nine times higher risk for abuse than children in homes where there was no IPV. ${ }^{108)}$

Research on the co-occurrence of child abuse and IPV has revealed a number of risk factors. Poverty is by far the most documented factor. ${ }^{117-119)}$ Other factors include prior substance use, mental illness, and crime in the family; ${ }^{111}$ fathers' use of drugs, alcohol, and arrest for criminal offenses; ${ }^{120)}$ substance use and depression within the family, lower education, and poor health; ${ }^{121)}$ and family conflict (e.g., marital conflict, parent alcohol use, unemployment), personal problems (e.g., parents' unfulfilled ambitions, lack of privacy, and loneliness), and external constraints (e.g., crime in the neighborhood, a lack of home conveniences, and physical remoteness). ${ }^{122)}$ Taken together, it is imperative not only to recognize the overlap of child abuse and exposure to IPV but also the context in which family violence occurs when addressing the hardships faced by disadvantaged children in vulnerable families.

While the consequences of child abuse and that of children's exposure to IPV are well documented, ${ }^{123)}$ less is known about the combined effects of child abuse and exposure to IPV. The few available studies suggest a compounding effect as evidenced by the higher internalizing and externalizing symptoms in children who were exposed to IPV and also experienced child abuse, compared to those who experienced only one form of the violence. ${ }^{124,125)}$ Furthermore, in an analysis of the data from the 1985 National Family Violence Survey, Cunningham ${ }^{126)}$ also found a compounding effect in terms of the risk for perpetrating abuse later in life for those who were both physically punished and exposed to IPV as a child.

\section{CHILDHOOD IPV EXPOSURE AND IPV VICTIMIZATION/PERPETRATION IN ADULTHOOD}

There is evidence that women who report childhood ad- 
versity, especially child sexual and physical abuse, are at a higher risk of IPV victimization in adulthood. For example, a systematic review of research studies on the intersection of adverse childhood experiences and IPV has found evidence that women who reported child physical and sexual abuse had an increased risk for IPV and that witnessing IPV as a child increased the likelihood of IPV victimization as adults. ${ }^{127)}$ Previously, the association between children exposed to IPV and later perpetration of IPV was also found in multiple studies. ${ }^{128-131)}$ Among the theories put forward to explain the association, the theory of stress sensitization suggests that childhood adversities including exposure to IPV increase an individual's vulnerability to subsequent stress. As such, the heightened negative emotional reactivity may persist into adulthood with an increased risk of IPV perpetration. ${ }^{130)}$ Additionally, gender differences in the association were also suggested. For example, Heyman and Smith Slep ${ }^{132)}$ found that for men, but not women, current IPV perpetration was uniquely associated with witnessing violence perpetrated by their fathers toward their mothers. Whitfield et al. ${ }^{133)}$ reported that the risk of IPV victimization increased if women had witnessed maternal IPV, however, for men whose mothers had been victims of IPV, a higher risk of perpetrating IPV was found. The neurobiological brain changes from adversity explained in detail above help explain these connections of witnessing IPV and experiencing child abuse with adolescent and adult use of violence in relationships.

The apparent association between childhood exposure to IPV and IPV perpetration/victimization in adulthood may add weight to the premise that transmission of violence may be intergenerational. ${ }^{134)}$ Interestingly, despite reports of deleterious outcomes, some children manage to find strengths and internal resilience in the face of adversity and utilize effective coping mechanisms to overcome the negative effects of ACE. ${ }^{135)}$

The increased risk for IPV victimization among children extends the concept of cumulative trauma through adolescence (teen dating violence which can be physical and/or sexual) and into adulthood with the myriad of adult IPV health outcomes compounded with childhood experiences of violence. ${ }^{136)}$

\section{ENHANCING RESILIENCE BY UNDERSTANDING THE IMPACT OF TRAUMA}

Despite the cumulative amount of work on resilience, definitions and conceptual frameworks often differ. For resilience research focusing on ACE, it is important to recognize that resilience is not static. Rather, it is a dynamic process that may vary over time and across developmental phases.
Thus, an individual's resilience status can change, for example, from resilience to non-resilience and vice versa. ${ }^{137)}$ Also, protective factors related to resilience following ACE have been identified and a good understanding of these factors is essential for promoting resilience. A previous review of these protective factors suggests that they can be divided into three levels: individual, familial, and community. ${ }^{137)}$ Personal characteristics, traits, and resources are considered individuallevel protective factors. Thus, children who actively engage in positive social activities, have strong internal locus of control, and aspire to high educational and personal achievements are reported to demonstrate higher resilience. Resources and supportive relationships such as stable caregiving are classified as family-level protective factors while peer relationships and non-family member social support are classified as community-level protective factors. ${ }^{135,137,138)}$ Based on the measurement of high competence and functioning following ACE as indicators of resilience, stable family environment and supportive relationships, the two family-level protective factors, have been linked consistently to more adaptive functioning. ${ }^{137)}$ 'Safe, stable, nurturing relationships and environments' are considered the basic building blocks needed to reduce violence against children thereby allowing children to reach their full potential. ${ }^{139)}$ There are numerous examples of interventions that encourage safe, stable, and nurturing relationships between parents and children and some of them are briefly described here.

Parent training programs are the most common interventions to enhance relationships between parents and their children and have the most evidence to suggest they are effective. ${ }^{140)}$ One example is the Positive Parenting Program (Triple P; http://www.triplep.net). ${ }^{141)}$ The Triple P Program is a popular program worldwide that aims to provide different levels of support to parents, from level 1 (providing information) to level 5 (sessions addressing severe childhood problems) and has been shown to prevent child maltreatment ${ }^{142)}$ and improve positive parenting. ${ }^{143-146)}$ Another program, The Positive Action Program (https://www.positiveaction.net/), which focuses on positive emotional-social skill building and involves a family and school component, has been found to decrease substance abuse and violence in youth. ${ }^{147,148)}$

Home visitation programs such as Nurse-Family Partnership (http://www.nursefamilypartnership.org/) and Early Head Start (https://eclkc.ohs.acf.hhs.gov/hslc/tta-system/ehsnrc/ about-ehs\#about) target vulnerable families and provide services such as family support through in-house visitation, health services to pregnant women, and early childhood and parent education. Home visitation programs have been shown in the US to prevent child maltreatment. ${ }^{149)} \mathrm{A}$ home visiting program in South Africa ${ }^{150)}$ suggests that more visits are associ- 
ated with increased cognitive development in the infants enrolled. In the US, the Domestic Violence Enhanced Home Visitation Program (DOVE) which combines 2 evidencebased interventions, a 10-minute brochure-based IPV intervention to be used within home visitation, has been tested in an a randomized controlled trial and demonstrated decreased IPV. $^{151)}$

Promoting social support is another type of program to strengthen parent and child relationships. ${ }^{152)}$ Circle of Parents (http://www.circleofparents.org) and Parents Anonymous (http://www.parentsanonymous.org) are examples of selfhelp groups for building social networks to provide peer support, increase problem-solving and coping skills, reduce social isolation, and strengthen parental communication.

Finally, through a variety of media formats, information is provided to parents in order to increase their parenting knowledge and strengthen their awareness of child maltreatment. ${ }^{153)}$ An example of media intervention is "families," a 12-episode television series in Australia that explores parenting strategies for coping with common behavioral problems in children.

Evidence relating to the effectiveness of the aforementioned interventions varies. For example, while strong evidence of effectiveness has been demonstrated for the Triple P Program $^{142-146)}$ the Positive Action Program; ${ }^{147,148)}$ and the NurseFamily Partnership Programs, ${ }^{150)}$ there is a need for more evidence concerning the effectiveness of social support and the media format programs for reducing child maltreatment. Also, in many evaluation studies, risk factors for child abuse (e.g., changes in parents' attitudes towards discipline) are used to evaluate effectiveness rather than the direct measure of reports of child abuse. In addition, there is generally a shortage of randomized controlled trials and studies on the costs and benefits of the intervention programs. Thus, more rigorously evaluated programs are needed in order to provide robust evidence on the prevention of child abuse and the economic benefits of the programs. Lastly, notwithstanding the positive results of some of the programs, the majority of the evaluations have been conducted in developed countries. More research is badly needed to assess the applicability and effectiveness of programs which focus on the promotion of safe, stable, and nurturing relationships in reducing child maltreatment in developing countries. ${ }^{154)}$

The $\mathrm{CDC}^{155)}$ and the $\mathrm{WHO}^{156)}$ have developed strategies based on the best evidence to date on reducing violence against children. These strategies include providing parent and caregiver support, increasing the economic strength of families, improving legal protections for children and families, developing effective services, and increasing access to education for children around the world. In addition, the US Office of Disease Prevention and Health Promotion's Healthy People
2020 emphasizes the importance of addressing the SDOH in ways that create social and physical environments that promote health and wellness for all. Examples would include safe and affordable housing, access to education, public safety, availability of healthy foods, and access to health care services. These strategies emphasize that to improve the health and well-being of the human family, we need interventions that focus on decreasing violence against children.

To summarize, evidence strongly suggests that childhood violence and abuse exposure are associated with short and long-term negative health and social consequences. Further, literature has also clearly identified the intersection of childhood experience of violence (as victim of child abuse and/or exposure to IPV) and IPV victimization/perpetration later in adulthood. As poly-victims in polyvictimization or victims in intergenerational violence, children and adults have been shown to have worse health and symptomatology. All these have implications for policy, research, and practice. Current policy in the US recognizes the need to screen for IPV which would facilitate the provision of interventions for the women and their children who screen positive. ${ }^{157)}$ Elsewhere in the world especially in developing countries, such screening policy is not common and much effort is needed to influence policy change. Health care providers are well-positioned to conduct the screening and provide care to abused women and their children. However, more evidence is required to validate the need for screening for other childhood adversities, in addition to increasing a solid base of robust evidence of intervention effectiveness.

The understanding of the intricate interplay between trauma and biology provides the health care community with new tools with which to enhance the health and well-being of children and adults. The fact that neurons change in response to external stimuli provides the basis for understanding the link between trauma and disease but, more importantly, provides a platform upon which to design effective therapies to help change the biology to promote the healing of those who have been hurt.

\section{Conflicts of Interest}

The authors have no financial conflicts of interest.

\section{REFERENCES}

1) Breiding MJ, Basile KC, Smith SG, Black MC, Mahendra R. Intimate partner violence surveillance: uniform definitions and recommended data elements, version 2.0. Atlanta, GA: National Center for Injury Prevention and Control, Centers for Disease Control and Prevention;2015.

2) Garcia-Moreno C, Jansen HA, Ellsberg M, Heise L, Watts CH; WHO Multi-country Study on Women's Health and Domestic Violence against Women Study Team. Prevalence of intimate partner violence: findings from the WHO multi-country study on women's 
health and domestic violence. Lancet 2006:368:1260-1269.

3) Black MC, Basile KC, Breiding MJ, Smith SG, Walters ML, Merrick MT, et al. The National intimate partner and sexual violence survey (NISVS): 2010 summary report. Atlanta, GA: National Center for Injury Prevention and Control, Centers for Disease Control and Prevention;2011.

4) Catalano S. Intimate partner violence, 1993-2010. Washington, DC: US Department of Justice, Office of Justice Programs, Bureau of Justice Statistics;2012.

5) McDonald R, Jouriles EN, Ramisetty-Mikler S, Caetano R, Green CE. Estimating the number of American children living in partner-violent families. J Fam Psychol 2006;20:137-142.

6) Moore CG, Probst JC, Tompkins M, Cuffe S, Martin AB. The prevalence of violent disagreements in US families: effects of residence, race/ethnicity, and parental stress. Pediatrics 2007;119 Suppl 1:S68S76.

7) Felitti VJ, Anda RF, Nordenberg D, Williamson DF, Spitz AM, Edwards V, et al. Relationship of childhood abuse and household dysfunction to many of the leading causes of death in adults. The adverse childhood experiences (ACE) study. Am J Prev Med 1998; 14:245-258.

8) Yoon PW, Bastian B, Anderson RN, Collins JL, Jaffe HW; Centers for Disease Control and Prevention (CDC). Potentially preventable deaths from the five leading causes of death--United States, 2008-2010. MMWR Morb Mortal Wkly Rep 2014;63:369374.

9) Finkelhor D, Shattuck A, Turner H, Hamby S. A revised inventory of adverse childhood experiences. Child Abuse Negl 2015;48: 13-21.

10) Wise PH. Child poverty and the promise of human capacity: childhood as a foundation for healthy aging. Acad Pediatr 2016;16(3 Suppl):S37-S45

11) Cronholm PF, Forke CM, Wade R, Bair-Merritt MH, Davis M, Harkins-Schwarz M, et al. Adverse childhood experiences: expanding the concept of adversity. Am J Prev Med 2015;49:354-361.

12) Anda RF, Butchart A, Felitti VJ, Brown DW. Building a framework for global surveillance of the public health implications of adverse childhood experiences. Am J Prev Med 2010;39:93-98.

13) Finkelhor D, Turner H, Ormrod R, Hamby SL. Violence, abuse, and crime exposure in a national sample of children and youth. Pediatrics 2009;124:1411-1423.

14) World Health Organization. Addressing adverse childhood experiences to improve public health. Proceedings of the WHO Expert Consultation-Meeting; 2009 May 4-5; Geneva. Geneva: World Health Organization;2014.

15) Richmond JM, Elliott AN, Pierce TW, Aspelmeier JE, Alexander AA. Polyvictimization, childhood victimization, and psychological distress in college women. Child Maltreat 2009;14:127-147.

16) Finkelhor D, Ormrod RK, Turner HA. Polyvictimization and trauma in a national longitudinal cohort. Dev Psychopathol 2007; 19:149-166.

17) Finkelhor D, Ormrod RK, Turner HA. Poly-victimization: a neglected component in child victimization. Child Abuse Negl 2007; $31: 7-26$

18) Sotero MM. A conceptual model of historical trauma: implications for public health practice and research. J Health Dispar Res Pract 2006;1:93-108.

19) Centers for Disease Control and Prevention, Kaiser Permanente. The ACE study survey data [unpublished data]. Atlanta, GA: US Department of Health and Human Services, Centers for Disease Control and Prevention;2016.

20) Centers for Disease Control and Prevention (CDC). Adverse childhood experiences reported by adults --- five states, 2009. MMWR Morb Mortal Wkly Rep 2010;59:1609-1613.

21) Gilbert LK, Breiding MJ, Merrick MT, Thompson WW, Ford
DC, Dhingra SS, et al. Childhood adversity and adult chronic disease: an update from ten states and the District of Columbia, 2010. Am J Prev Med 2015;48:345-349.

22) Bellis MA, Hughes K, Leckenby N, Jones L, Baban A, Kachaeva M, et al. Adverse childhood experiences and associations with health-harming behaviours in young adults: surveys in eight eastern European countries. Bull World Health Organ 2014;92:641-655.

23) Al-Shawi AF, Lafta RK. Effect of adverse childhood experiences on physical health in adulthood: results of a study conducted in Baghdad city. J Family Community Med 2015;22:78-84.

24) Soares AL, Howe LD, Matijasevich A, Wehrmeister FC, Menezes AM, Gonçalves H. Adverse childhood experiences: prevalence and related factors in adolescents of a Brazilian birth cohort. Child Abuse Negl 2016;51:21-30.

25) Bellis MA, Hughes K, Leckenby N, Perkins C, Lowey H. National household survey of adverse childhood experiences and their relationship with resilience to health-harming behaviors in England. BMC Med 2014;12:72.

26) Ramiro LS, Madrid BJ, Brown DW. Adverse childhood experiences (ACE) and health-risk behaviors among adults in a developing country setting. Child Abuse Negl 2010;34:842-855.

27) Paunovic M, Markovic M, Vojvodic K, Neskovic A, Sethi D, Grbic M. Survey of adverse childhood experiences among Serbian university students-report from the 2013/2014 survey. Copenhagen: WHO Regional Office for Europe;2015.

28) Fonseka RW, Minnis AM, Gomez AM. Impact of adverse childhood experiences on intimate partner violence perpetration among Sri Lankan men. PLoS One 2015;10:e136321.

29) Tran QA, Dunne MP, Vo TV, Luu NH. Adverse childhood experiences and the health of university students in eight provinces of Vietnam. Asia Pac J Public Health 2015;27(8 Suppl):26S-32S.

30) Almuneef M, Qayad M, Aleissa M, Albuhairan F. Adverse childhood experiences, chronic diseases, and risky health behaviors in Saudi Arabian adults: a pilot study. Child Abuse Negl 2014;38:17871793.

31) Anda RF, Brown DW. Root causes and organic budgeting: funding health from conception to the grave. Pediatr Health 2007;1:141-143.

32) Dube SR, Felitti VJ, Dong M, Giles WH, Anda RF. The impact of adverse childhood experiences on health problems: evidence from four birth cohorts dating back to 1900. Prev Med 2003;37:268-277.

33) Edwards VJ, Holden GW, Felitti VJ, Anda RF. Relationship between multiple forms of childhood maltreatment and adult mental health in community respondents: results from the adverse childhood experiences study. Am J Psychiatry 2003;160:1453-1460.

34) Felitti VJ. Long-term medical consequences of incest, rape, and molestation. South Med J 1991;84:328-331.

35) Oladeji BD, Makanjuola VA, Gureje O. Family-related adverse childhood experiences as risk factors for psychiatric disorders in Nigeria. Br J Psychiatry 2010;196:186-191.

36) Putnam KT, Harris WW, Putnam FW. Synergistic childhood adversities and complex adult psychopathology. J Trauma Stress 2013; 26:435-442

37) Hillis SD, Anda RF, Felitti VJ, Nordenberg D, Marchbanks PA. Adverse childhood experiences and sexually transmitted diseases in men and women: a retrospective study. Pediatrics 2000;106: E11.

38) Dietz PM, Spitz AM, Anda RF, Williamson DF, McMahon PM, Santelli JS, et al. Unintended pregnancy among adult women exposed to abuse or household dysfunction during their childhood. JAMA 1999;282:1359-1364.

39) Eberhard-Gran M, Schei B, Eskild A. Somatic symptoms and diseases are more common in women exposed to violence. J Gen Intern Med 2007;22:1668-1673.

40) Tietjen GE, Khubchandani J, Herial NA, Shah K. Adverse childhood experiences are associated with migraine and vascular bio- 
markers. Headache 2012;52:920-929.

41) Dong M, Dube SR, Felitti VJ, Giles WH, Anda RF. Adverse childhood experiences and self-reported liver disease: new insights into the causal pathway. Arch Intern Med 2003;163:1949-1956.

42) Brown DW, Anda RF, Felitti VJ, Edwards VJ, Malarcher AM, Croft JB, et al. Adverse childhood experiences are associated with the risk of lung cancer: a prospective cohort study. BMC Public Health 2010;10:20.

43) Fuller-Thomson E, Brennenstuhl S. Making a link between childhood physical abuse and cancer: results from a regional representative survey. Cancer 2009;115:3341-3350.

44) Kelly-Irving M, Lepage B, Dedieu D, Lacey R, Cable N, Bartley M, et al. Childhood adversity as a risk for cancer: findings from the 1958 British birth cohort study. BMC Public Health 2013;13:767.

45) Rich-Edwards JW, Spiegelman D, Lividoti Hibert EN, Jun HJ, Todd TJ, Kawachi I, et al. Abuse in childhood and adolescence as a predictor of type 2 diabetes in adult women. Am J Prev Med 2010;39:529-536.

46) Anda RF, Brown DW, Dube SR, Bremner JD, Felitti VJ, Giles WH. Adverse childhood experiences and chronic obstructive pulmonary disease in adults. Am J Prev Med 2008;34:396-403.

47) Subramanian SV, Ackerson LK, Subramanyam MA, Wright RJ. Domestic violence is associated with adult and childhood asthma prevalence in India. Int J Epidemiol 2007;36:569-579.

48) Fuller-Thomson E, Brennenstuhl S, Frank J. The association between childhood physical abuse and heart disease in adulthood: findings from a representative community sample. Child Abuse Negl 2010;34:689-698.

49) Su S, Wang X, Kapuku GK, Treiber FA, Pollock DM, Harshfield GA, et al. Adverse childhood experiences are associated with detrimental hemodynamics and elevated circulating endothelin-1 in adolescents and young adults. Hypertension 2014;64:201-207.

50) Brown DW, Anda RF, Tiemeier H, Felitti VJ, Edwards VJ, Croft JB, et al. Adverse childhood experiences and the risk of premature mortality. Am J Prev Med 2009;37:389-396.

51) Chen E, Turiano NA, Mroczek DK, Miller GE. Association of reports of childhood abuse and all-cause mortality rates in women. JAMA Psychiatry 2016;73:920-927.

52) Fang $X$, Corso PS. Child maltreatment, youth violence, and intimate partner violence: developmental relationships. Am J Prev Med 2007;33:281-290.

53) Fox BH, Perez N, Cass E, Baglivio MT, Epps N. Trauma changes everything: examining the relationship between adverse childhood experiences and serious, violent and chronic juvenile offenders. Child Abuse Neg1 2015;46:163-173.

54) Kim HS, Kim HS. The impact of family violence, family functioning, and parental partner dynamics on Korean juvenile delinquency. Child Psychiatry Hum Dev 2008;39:439-453.

55) Naramore R, Bright MA, Epps N, Hardt NS. Youth arrested for trading sex have the highest rates of childhood adversity: a statewide study of juvenile offenders. Sex Abuse 2017;29:396-410.

56) Wolff KT, Baglivio MT, Piquero AR. The relationship between adverse childhood experiences and recidivism in a sample of juvenile offenders in community-based treatment. Int J Offender Ther Comp Criminol 2015 Nov 12 [Epub ahead of print]. https://doi. org/10.1177/0306624X15613992.

57) Bethell CD, Newacheck P, Hawes E, Halfon N. Adverse childhood experiences: assessing the impact on health and school engagement and the mitigating role of resilience. Health Aff (Millwood) 2014;33:2106-2115.

58) Emery CR. Controlling for selection effects in the relationship between child behavior problems and exposure to intimate partner violence. J Interpers Violence 2011;26:1541-1558.

59) Humphreys KL, Zeanah CH. Deviations from the expectable environment in early childhood and emerging psychopathology.
Neuropsychopharmacology 2015;40:154-170.

60) Johnson RM, Kotch JB, Catellier DJ, Winsor JR, Dufort V, Hunter W, et al. Adverse behavioral and emotional outcomes from child abuse and witnessed violence. Child Maltreat 2002;7:179186.

61) Kaslow NJ, Thompson MP. Associations of child maltreatment and intimate partner violence with psychological adjustment among low SES, African American children. Child Abuse Negl 2008;32:888-896.

62) Kernic MA, Wolf ME, Holt VL, McKnight B, Huebner CE, Rivara FP. Behavioral problems among children whose mothers are abused by an intimate partner. Child Abuse Negl 2003;27:12311246.

63) Kiernan KE, Huerta MC. Economic deprivation, maternal depression, parenting and children's cognitive and emotional development in early childhood. Br J Sociol 2008;59:783-806.

64) Roustit C, Chaix B, Chauvin P. Family breakup and adolescents' psychosocial maladjustment: public health implications of family disruptions. Pediatrics 2007;120:e984-e991.

65) Silverstein M, Augustyn M, Young R, Zuckerman B. The relationship between maternal depression, in-home violence and use of physical punishment: what is the role of child behaviour? Arch Dis Child 2009;94:138-143.

66) Whitaker RC, Orzol SM, Kahn RS. Maternal mental health, substance use, and domestic violence in the year after delivery and subsequent behavior problems in children at age 3 years. Arch Gen Psychiatry 2006;63:551-560.

67) Burke NJ, Hellman JL, Scott BG, Weems CF, Carrion VG. The impact of adverse childhood experiences on an urban pediatric population. Child Abuse Negl 2011;35:408-413.

68) Heerman WJ, Krishnaswami S, Barkin SL, McPheeters M. Adverse family experiences during childhood and adolescent obesity. Obesity (Silver Spring) 2016;24:696-702.

69) Lynch BA, Agunwamba A, Wilson PM, Kumar S, Jacobson RM, Phelan S, et al. Adverse family experiences and obesity in children and adolescents in the United States. Prev Med 2016;90:148154.

70) Pretty C, O’Leary DD, Cairney J, Wade TJ. Adverse childhood experiences and the cardiovascular health of children: a cross-sectional study. BMC Pediatr 2013;13:208

71) Clougherty JE, Levy JI, Kubzansky LD, Ryan PB, Suglia SF, Canner MJ, et al. Synergistic effects of traffic-related air pollution and exposure to violence on urban asthma etiology. Environ Health Perspect 2007;115:1140-1146.

72) Suglia SF, Enlow MB, Kullowatz A, Wright RJ. Maternal intimate partner violence and increased asthma incidence in children: buffering effects of supportive caregiving. Arch Pediatr Adolesc Med 2009;163:244-250

73) Wing R, Gjelsvik A, Nocera M, McQuaid EL. Association between adverse childhood experiences in the home and pediatric asthma. Ann Allergy Asthma Immunol 2015;114:379-384.

74) Klassen SA, Chirico D, O'Leary DD, Cairney J, Wade TJ. Linking systemic arterial stiffness among adolescents to adverse childhood experiences. Child Abuse Negl 2016;56:1-10.

75) Flaherty EG, Thompson R, Dubowitz H, Harvey EM, English DJ, Proctor LJ, et al. Adverse childhood experiences and child health in early adolescence. JAMA Pediatr 2013;167:622-629.

76) Balistreri KS, Alvira-Hammond M. Adverse childhood experiences, family functioning and adolescent health and emotional well-being. Public Health 2016;132:72-78.

77) Delaney-Black V, Covington C, Ondersma SJ, Nordstrom-Klee B, Templin T, Ager J, et al. Violence exposure, trauma, and IQ and/ or reading deficits among urban children. Arch Pediatr Adolesc Med 2002;156:280-285.

78) Fuller-Thomson E, Hooper SR. The association between child- 
hood physical abuse and dyslexia: findings from a populationbased study. J Interpers Violence 2015;30:1583-1592.

79) Gilbert AL, Bauer NS, Carroll AE, Downs SM. Child exposure to parental violence and psychological distress associated with delayed milestones. Pediatrics 2013;132:e1577-e1583.

80) Guinosso SA, Johnson SB, Riley AW. Multiple adverse experiences and child cognitive development. Pediatr Res 2016;79:220-226.

81) Jimenez ME, Wade R Jr, Lin Y, Morrow LM, Reichman NE. Adverse experiences in early childhood and kindergarten outcomes. Pediatrics 2016;137:e20151839.

82) Anda RF, Croft JB, Felitti VJ, Nordenberg D, Giles WH, Williamson DF, et al. Adverse childhood experiences and smoking during adolescence and adulthood. JAMA 1999;282:1652-1658.

83) Anda RF, Chapman DP, Felitti VJ, Edwards V, Williamson DF, Croft JB, et al. Adverse childhood experiences and risk of paternity in teen pregnancy. Obstet Gynecol 2002;100:37-45.

84) Dube SR, Felitti VJ, Dong M, Chapman DP, Giles WH, Anda RF. Childhood abuse, neglect, and household dysfunction and the risk of illicit drug use: the adverse childhood experiences study. Pediatrics 2003;111:564-572.

85) Dube SR, Anda RF, Felitti VJ, Chapman DP, Williamson DF, Giles WH. Childhood abuse, household dysfunction, and the risk of attempted suicide throughout the life span: findings from the adverse childhood experiences study. JAMA 2001;286:3089-3096.

86) Rothman EF, Edwards EM, Heeren T, Hingson RW. Adverse childhood experiences predict earlier age of drinking onset: results from a representative US sample of current or former drinkers. Pediatrics 2008;122:e298-e304.

87) Felitti VJ. Childhood sexual abuse, depression, and family dysfunction in adult obese patients: a case control study. South Med J 1993;86:732-736.

88) Shonkoff JP, Boyce WT, McEwen BS. Neuroscience, molecular biology, and the childhood roots of health disparities: building a new framework for health promotion and disease prevention. JAMA 2009;301:2252-2259.

89) Teicher MH, Samson JA. Annual research review: enduring neurobiological effects of childhood abuse and neglect. J Child Psychol Psychiatry 2016;57:241-266.

90) Marmot M, Friel S, Bell R, Houweling TA, Taylor S; Commission on Social Determinants of Health. Closing the gap in a generation: health equity through action on the social determinants of health. Lancet 2008;372:1661-1669.

91) Shonkoff JP, Garner AS; Committee on Psychosocial Aspects of Child and Family Health; Committee on Early Childhood, Adoption, and Dependent Care; Section on Developmental and Behavioral Pediatrics. The lifelong effects of early childhood adversity and toxic stress. Pediatrics 2012;129:e232-e246.

92) McEwen BS, Stellar E. Stress and the individual. Mechanisms leading to disease. Arch Intern Med 1993;153:2093-2101.

93) McEwen BS. Physiology and neurobiology of stress and adaptation: central role of the brain. Physiol Rev 2007;87:873-904.

94) McLaughlin KA, Sheridan MA, Lambert HK. Childhood adversity and neural development: deprivation and threat as distinct dimensions of early experience. Neurosci Biobehav Rev 2014;47:578591.

95) Andersen SL, Tomada A, Vincow ES, Valente E, Polcari A, Teicher MH. Preliminary evidence for sensitive periods in the effect of childhood sexual abuse on regional brain development. J Neuropsychiatry Clin Neurosci 2008;20:292-301.

96) Choi J, Jeong B, Rohan ML, Polcari AM, Teicher MH. Preliminary evidence for white matter tract abnormalities in young adults exposed to parental verbal abuse. Biol Psychiatry 2009;65:227-234.

97) Lupien SJ, McEwen BS, Gunnar MR, Heim C. Effects of stress throughout the lifespan on the brain, behaviour and cognition. Nat Rev Neurosci 2009;10:434-445.
98) Masten CL, Guyer AE, Hodgdon HB, McClure EB, Charney DS, Ernst M, et al. Recognition of facial emotions among maltreated children with high rates of post-traumatic stress disorder. Child Abuse Negl 2008;32:139-153.

99) Moffitt TE; Klaus-Grawe 2012 Think Tank. Childhood exposure to violence and lifelong health: clinical intervention science and stress-biology research join forces. Dev Psychopathol 2013;25(4 Pt 2):1619-1634.

100) Shalev I. Early life stress and telomere length: investigating the connection and possible mechanisms: a critical survey of the evidence base, research methodology and basic biology. Bioessays 2012;34:943-952.

101) Lamers-Winkelman F, Willemen AM, Visser M. Adverse childhood experiences of referred children exposed to intimate partner violence: consequences for their wellbeing. Child Abuse Negl 2012;36:166-179.

102) Dube SR, Anda RF, Felitti VJ, Edwards VJ, Williamson DF. Exposure to abuse, neglect, and household dysfunction among adults who witnessed intimate partner violence as children: implications for health and social services. Violence Vict 2002;17:3-17.

103) Thompson RS, Bonomi AE, Anderson M, Reid RJ, Dimer JA, Carrell D, et al. Intimate partner violence: prevalence, types, and chronicity in adult women. Am J Prev Med 2006;30:447-457.

104) Campbell JC. Health consequences of intimate partner violence. Lancet 2002;359:1331-1336.

105) Fantuzzo J, Boruch R, Beriama A, Atkins M, Marcus S. Domestic violence and children: prevalence and risk in five major U.S. cities. J Am Acad Child Adolesc Psychiatry 1997;36:116-122.

106) Edleson JL. Problems associated with children's witnessing of domestic violence. Harrisburg, PA: The National Online Resource Center on Violence Against Women, National Resource Center on Domestic Violence; 1999.

107) Lichter EL, McCloskey LA. The effects of childhood exposure to marital violence on adolescent gender-role beliefs and dating violence. Psychol Women Q 2004;28:344-357.

108) Moffitt TE, Caspi A. Preventing the intergenerational continuity of antisocial behaviour: implications of partner violence. In: Farrington DP, Coid JW, editors. Early prevention of adult antisocial behaviour. Cambridge: Cambridge University Press;2003. p.109129.

109) Guterman NB. Advancing prevention research on child abuse, youth violence, and domestic violence: emerging strategies and issues. J Interpers Violence 2004;19:299-321.

110) Belanger CF, Hennekens CH, Rosner B, Speizer FE. The Nurses' Health Study. Am J Nurs 1978;78:1039-1040.

111) Dong M, Anda RF, Felitti VJ, Dube SR, Williamson DF, Thompson TJ, et al. The interrelatedness of multiple forms of childhood abuse, neglect, and household dysfunction. Child Abuse Negl 2004; 28:771-784.

112) Appel AE, Holden GW. The co-occurrence of spouse and physical child abuse: a review and appraisal. J Fam Psychol 1998;12:578-599.

113) Gewirtz AH, Edleson JL. Young children's exposure to intimate partner violence: towards a developmental risk and resilience framework for research and intervention. J Fam Violence 2007;22:151163.

114) Osofsky JD. The impact of violence on children. Future Child 1999; 9:33-49.

115) Renner LM, Slack KS. Intimate partner violence and child maltreatment: understanding intra- and intergenerational connections. Child Abuse Negl 2006;30:599-617.

116) Tajima EA. The relative importance of wife abuse as a risk factor for violence against children. Child Abuse Negl 2000;24:1383-1398.

117) Greenfield EA. Child abuse as a life-course social determinant of adult health. Maturitas 2010;66:51-55.

118) Antai D, Braithwaite P, Clerk G. Social determinants of child abuse: 
evidence of factors associated with maternal abuse from the Egypt demographic and health survey. J Inj Violence Res 2016;8:25-34.

119) Braveman P, Gottlieb L. The social determinants of health: it's time to consider the causes of the causes. Public Health Rep 2014;129 Suppl 2:19-31.

120) Hartley CC. The co-occurrence of child maltreatment and domestic violence: examining both neglect and child physical abuse. Child Maltreat 2002;7:349-358.

121) Tajima EA. Correlates of the co-occurrence of wife abuse and child abuse among a representative sample. J Fam Violence 2004;19:391402.

122) Herrenkohl TI, Herrenkohl RC. Examining the overlap and prediction of multiple forms of child maltreatment, stressors, and socioeconomic status: a longitudinal analysis of youth outcomes. J Fam Violence 2007:22:553-562.

123) Herrenkohl TI, Sousa C, Tajima EA, Herrenkohl RC, Moylan CA. Intersection of child abuse and children's exposure to domestic violence. Trauma Violence Abuse 2008;9:84-99.

124) McCloskey LA, Figueredo AJ, Koss MP. The effects of systemic family violence on children's mental health. Child Dev 1995;66:12391261.

125) Wolfe DA, Crooks CV, Lee V, McIntyre-Smith A, Jaffe PG. The effects of children's exposure to domestic violence: a meta-analysis and critique. Clin Child Fam Psychol Rev 2003;6:171-187.

126) Cunningham SM. The joint contribution of experiencing and witnessing violence during childhood on child abuse in the parent role. Violence Vict 2003;18:619-639.

127) Montalvo-Liendo N, Fredland N, McFarlane J, Lui F, Koci AF, Nava A. The intersection of partner violence and adverse childhood experiences: implications for research and clinical practice. Issues Ment Health Nurs 2015;36:989-1006.

128) Ehrensaft MK, Cohen P, Brown J, Smailes E, Chen H, Johnson JG. Intergenerational transmission of partner violence: a 20 -year prospective study. J Consult Clin Psychol 2003;71:741-753.

129) McKinney CM, Caetano R, Ramisetty-Mikler S, Nelson S. Childhood family violence and perpetration and victimization of intimate partner violence: findings from a national population-based study of couples. Ann Epidemiol 2009;19:25-32.

130) Roberts AL, McLaughlin KA, Conron KJ, Koenen KC. Adulthood stressors, history of childhood adversity, and risk of perpetration of intimate partner violence. Am J Prev Med 2011;40:128-138

131) Stith SM, Rosen KH, Middleton KA, Busch AL, Lundeberg K, Carlton RP. The intergenerational transmission of spouse abuse: a meta-analysis. J Marriage Fam 2000;62:640-654

132) Heyman RE, Smith Slep AM. Do child abuse and interparental violence lead to adulthood family violence? J Marriage Fam 2002;64: 864-870.

133) Whitfield CL, Anda RF, Dube SR, Felitti VJ. Violent childhood experiences and the risk of intimate partner violence in adults: assessment in a large health maintenance organization. J Interpers Violence 2003;18:166-185.

134) Roberts AL, Gilman SE, Fitzmaurice G, Decker MR, Koenen KC. Witness of intimate partner violence in childhood and perpetration of intimate partner violence in adulthood. Epidemiology 2010;21:809-818.

135) Suzuki SL, Geffner R, Bucky SF. The experiences of adults exposed to intimate partner violence as children: an exploratory qualitative study of resilience and protective factors. J Emot Abuse 2008;8: 103-121.

136) Davies L, Ford-Gilboe M, Willson A, Varcoe C, Wuest J, Campbell J, et al. Patterns of cumulative abuse among female survivors of intimate partner violence: links to women's health and socioeconomic status. Violence Against Women 2015;21:30-48.

137) Afifi TO, Macmillan HL. Resilience following child maltreatment: a review of protective factors. Can J Psychiatry 2011;56:266-272.
138) Howell KH. Resilience and psychopathology in children exposed to family violence. Aggress Violent Behav 2011;16:562-569.

139) Centers for Disease Control and Prevention. Essentials for childhood: steps to create safe, stable, nurturing relationships and environments. Atlanta, GA: National Center for Injury Prevention and Control, Centers for Disease Control and Prevention;2014.

140) Furlong M, McGilloway S, Bywater T, Hutchings J, Smith SM, Donnelly M. Cochrane review: behavioural and cognitive-behavioural group-based parenting programmes for early-onset conduct problems in children aged 3 to 12 years (review). Evid Based Child Health 2013;8:318-692.

141) Sanders MR. Triple P-Positive Parenting Program: towards an empirically validated multilevel parenting and family support strategy for the prevention of behavior and emotional problems in children. Clin Child Fam Psychol Rev 1999;2:71-90.

142) Pickering JA, Sanders MR. Reducing child maltreatment by making parenting programs available to all parents: a case example using the Triple P-Positive Parenting Program. Trauma Violence Abuse 2016;17:398-407.

143) Heinrichs N, Kliem S, Hahlweg K. Four-year follow-up of a randomized controlled trial of triple $\mathrm{p}$ group for parent and child outcomes. Prev Sci 2014;15:233-245.

144) de Graaf I, Speetjens P, Smit F, de Wolff M, Tavecchio L. Effectiveness of the Triple P Positive Parenting Program on behavioral problems in children: a meta-analysis. Behav Modif 2008;32:714-735.

145) Prinz RJ, Sanders MR, Shapiro CJ, Whitaker DJ, Lutzker JR. Population-based prevention of child maltreatment: the U.S. Triple P system population trial. Prev Sci 2009;10:1-12.

146) Sanders MR. Development, evaluation, and multinational dissemination of the Triple P-Positive Parenting Program. Annu Rev Clin Psychol 2012;8:345-379.

147) Beets MW, Flay BR, Vuchinich S, Snyder FJ, Acock A, Li KK, et al. Use of a social and character development program to prevent substance use, violent behaviors, and sexual activity among elementary-school students in Hawaii. Am J Public Health 2009;99:14381445.

148) Washburn IJ, Acock A, Vuchinich S, Snyder F, Li KK, Ji P, et al. Effects of a social-emotional and character development program on the trajectory of behaviors associated with social-emotional and character development: findings from three randomized trials. Prev Sci 2011;12:314-323.

149) Bilukha O, Hahn RA, Crosby A, Fullilove MT, Liberman A, Moscicki E, et al. The effectiveness of early childhood home visitation in preventing violence: a systematic review. Am J Prev Med 2005;28(2 Suppl 1):11-39.

150) Rotheram-Borus MJ, Tomlinson M, le Roux IM, Harwood JM, Comulada S, O'Connor MJ, et al. A cluster randomised controlled effectiveness trial evaluating perinatal home visiting among South African mothers/infants. PLoS One 2014;9:e105934.

151) Sharps PW, Bullock LF, Campbell JC, Alhusen JL, Ghazarian SR, Bhandari SS, et al. Domestic violence enhanced perinatal home visits: the DOVE randomized clinical trial. J Womens Health (Larchmt) 2016;25:1129-1138.

152) Budde S, Schene P. Informal social support interventions and their role in violence prevention: an agenda for future evaluation. J Interpers Violence 2004;19:341-355.

153) Sanders MR, Markie-Dadds C, Tully LA, Bor W. The Triple P-Positive Parenting Program: a comparison of enhanced, standard, and self-directed behavioral family intervention for parents of children with early onset conduct problems. J Consult Clin Psychol 2000;68: 624-640

154) World Health Organization. Preventing violence through the development of safe, stable and nurturing relationships between children and their parents and caregivers. Geneva: World Health Organization;2009. 
155) Hillis SD, Mercy JA, Saul J, Gleckel J, Abad N, Kress H. THRIVES: a global technical package to prevent violence against children. Atlanta, GA: Centers for Disease Control and Prevention;2015.

156) World Health Organization. INSPIRE: seven strategies for ending violence against children. Geneva: World Health Organization;
2016.

157) Moyer VA; U.S. Preventive Services Task Force. Screening for intimate partner violence and abuse of elderly and vulnerable adults: U.S. preventive services task force recommendation statement. Ann Intern Med 2013;158:478-486. 